\title{
A CONDIÇÃO DE PROLETARIEDADE: ESBOÇO DE UMA ANALÍTICA EXISTENCIAL DA CLASSE DO PROLETARIADO
}

\author{
Giovanni Antonio Pinto Alves ${ }^{1}$ \\ e Esdras Fred Rodrigues Selegrin ${ }^{2}$
}

\begin{abstract}
Resumo
Nosso objetivo neste artigo é apresentar o conceito de "condição de proletariedade", considerado por nós como a condição existencial fundamental (e fundante) da modernidade do capital, que implica homens e mulheres despossuídos dos meios de produção de sua vida social, na situação de "classe social" do proletariado. A "classe" (entre aspas) do proletariado é o conjunto social de homens e mulheres, alienados da propriedade/controle social dos meios de produção da vida, que estão subsumidos a uma condição existencial histórico-particular: a condição de proletariedade.
\end{abstract}

Palavras-chave: Capitalismo. Classe social. Proletariado. Consciência de classe.

\footnotetext{
${ }^{1}$ Livre-docente, Universidade Estadual Paulista - UNESP/Campus de Marília. giovanni.alves@ uol.com.br

${ }^{2}$ Mestrando em Ciências Sociais, pelo Programa de Pós-Graduação em Ciências Sociais da Universidade Estadual Paulista - UNESP/Campus de Marília. esdrasselegrin@yahoo.com.br
} 


\title{
THE PROLETARIAN CONDITION: AN OUTLINE OF AN EXISTENTIAL ANALYSIS OF THE PROLETARIAT
}

\begin{abstract}
Our objective is to present the concept of "proletariancondition", considered by us as the fundamental existential condition (and foundational) of modern finances, which involves men and women deprived of the means of production for their social life,in the situation of «social class» of the proletariat. The (quote, unquote) «class» of the proletariat is the social group of men and women, alienated from the social ownership/control of the means of life production, who are subsumed to a particular historical existential condition: the condition of proletarians.
\end{abstract}

Keywords: Capitalism. Social class. Proletariat. Class awareness.

analítica existencial do proletariado a partir do conceito de "condição
de proletariedade" pode ser considerada a base categorial-objetiva para
construirmos, na perspectiva dialético-materialista, uma teoria da classe social do proletariado que consiga, por um lado, romper com as incrustações positivistas que impregnam as elaborações sociológicas (e marxistas) do conceito de classe social e, por outro lado, salientar a centralidade ontológica do processo de formação do sujeito histórico de classe capaz de promover a práxis emancipatória no século XXI. Entretanto, nosso objetivo, neste pequeno ensaio, é mais modesto, isto é, pretendemos tão somente esclarecer o significado da categoria de condição de proletariedade e sua distinção do conceito de classe social do proletariado.

Para nós, enquanto "classe" diz respeito ao sujeito histórico capaz de ação social e política, em si e para si (e para além de si), capaz de "negação da negação" da alienação em suas múltiplas determinações; a "condição de proletariedade" designa a condição existencial objetiva historicamente constituída pelo modo de produção do capital e no interior da qual pode (ou não) se constituir o sujeito histórico de classe. A condição de proletariedade é uma categoria social descritiva dos atributos existenciais das individualidades pessoais de "classe" subsumidas ao mododeproduçãocapitalista. Estar imerso nacondição existencial deproletariedade não significa necessariamente pertencer à classe social do proletariado. Nesse caso, são apenas proletários, homens e mulheres da "multidão" ou homens e mulheres do "povo" que pertencem à "classe" do proletariado (com aspas). A multidão e 0 
povo designam as individualidades pessoais imersas na condição de proletariedade que expressa o ser-aí (dasein) de homens e mulheres reduzidos objetivamente à condição de alienação e estranhamento social. A multidão e o povo se constituem como classe no sentido pleno do conceito quando se indignam, resistem individual ou coletivamente, ou ainda, organizam-se e lutam, em si e para si, como sujeito histórico de classe capaz de mudança social contra a condição de proletariedade. A constituição do "em-si" e "para-si" da classe percorre um longo (e complexo) continuum que vai da contingência à necessidade histórica.

0 conceito de "classe social" é um dos mais cruciais conceitos para a explicação crítico-ontológica da práxis humano-social na sociedade burguesa. Existe uma densa, rica e controversa elaboração teórico-analítica do conceito de classe social nas ciências sociais e principalmente no marxismo do século XX (SILVA, 2009; GIDDENS; HELD, 1982; ESTANQUE, 1997). Entretanto, não temos a mínima pretensão de expor, neste ensaio, os desdobramentos sinuosos deste instigante debate marxista (ou sociológico). Nas várias elaborações do conceito de "classe social" entre os marxistas no século XX, perpassa a candente tensão entre estruturas e condições objetivas, por um lado; e sujeitos, ações coletivas e identidades, por outro.

Por um lado, alguns marxistas estruturalistas (ALTHUSSER; BALIBAR, 1973; POULANTZAS, 1975; COHEN, 1978) salientam as condições objetivas para descrever as classes sociais reduzidas a "lugares" ou "posições" nas estruturas de produção historicamente determinados. As classes sociais seriam produzidas, dum ponto de vista altamente abstrato, pela estrutura e pela dinâmica dos modos de produção. Para eles, a organização social da produção é a principal instância que determina os lugares estruturais "vazios" a ser preenchidos e ocupados pela posição dos agentes sociais, vistos como simples portadores desses lugares ou funções resultantes da estrutura de classes. Na verdade, os agentes sociais surgem como efeitos da "determinação estrutural de classes". Nesse caso, o conceito de classes sociais tem um tratamento meramente descritivo, que pode ser aplicado a outros modos de produção (pode-se referir assim a estrutura de classes na Antiguidade ou na Idade Média, por exemplo). Nesta perspectiva, o conceito de "classe social" do proletariado perde sua dimensão histórico-categorial intrínseca à modernidade do capital e sua vinculação ontológica à constituição efetiva do sujeito histórico capaz de "negação da negação". Mesmo autores como Erik Olin Wright (1985; 1998) e inclusive Bourdieu (1979; 1980), apesar de serem críticos do marxismo estruturalista, procurando desenvolver uma análise do conceito de classe em termos multidimensionais e níveis diferenciados, mas complementares 
de análise, não conseguem ir além do procedimento descritivo e fatorialista da classe posta como um datum sociológico.

Por outro lado, outros autores marxistas, como E.P. Thompson (1982) e Antonio Gramsci (1974), ou ainda Hobsbawm (2003) e Brenner (1998) tendem a salientar que a determinação mais relevante na configuração das classes sociais não seria a estrutura de classes, mas sim, os processos históricos, as práticas culturais, as sociabilidades, experiências e lutas vividas pelos agentes sociais nos locais de trabalho e cotidiano. Estas determinações históricas, sociais, políticas e culturais seriam decisivas na formação de classe, com o desenvolvimento da consciência de classe, a organização e mobilização de classe. Nesse caso, o conceito de classe social não seria um datum sociológico, mas como observou Thompson, "um fenômeno histórico, algo que de fato ocorre nas relações humanas" (THOMPSON, 1982).

Ora, para nós, "classe social" não éuma categoria descritiva, mas sim, o que denominamos de categoria-espectral no sentido de categoria social como forma de ser ou determinação da existência, capaz de expressar o devir histórico-coletivo de individualidades pessoais subsumidas na condição de proletariedade. Nesse caso, a categoria "classe social" implica uma densa articulação entre objetividade e subjetividade que não se reduz a meros "lugares", "posições" determinados por "fatores" econômicos, políticos ou ideológicos. Na ótica dialética (e ontológica), o conceito de classe social e consciência de classe expressam, em si e para si, a interconexão essencial entre liberdade e necessidade, teleologia e causalidade, objetividade e subjetividade do homem que trabalha, sendo, deste modo, ao lado do conceito de práxis, um dos mais importantes conceitos das ciências sociais capaz de explicar a mudança histórica. Renegá-lo, como fazem hoje, é abdicar da lucidez necessária para apreender o movimento do real.

\section{EXPLORAÇÃO E ESTRANHAMENTO}

Numprimeiromomento,éimportantesalientaradistinçãocrucial,nolegado marxiano, entre teoria do estranbamento e teoria da exploração, destacando que o conceito de classe social do proletariado que iremos apresentar, a partir do conceito de condição de proletariedade, tem como base teórico-metodológica, a teoria do estranbamento cujos princípios fundamentais foram expostos por Karl Marx nos "Manuscritos de Paris", de 1844. Estas distinções categoriais - teoria do estranhamento/teoria da exploração, "classe" do proletariado (com aspas) e a classe social do proletariado e o conceito de condição de proletariedade - são elementos categoriais importantes para construirmos uma teoria da classe social do proletariado capaz de ir além do viés estrutural-positivista. 
Pode-se dividir, a título meramente beurístico, a teoria de Marx e sua critica do capital, pelo menos em duas construções teórico-analíticas fundamentais: teoria da exploração e teoria do estranbamento.

A teoria da exploração é o complexo categorial que explica a dinâmica estrutural de produção e acumulação de valor, telos (ou finalidade intrínseca) do sistema de controle sociometabólico do capital. Para explicar a produção do capital, Marx explicitou em seus textos, as categorias de mais-valia, trabalho abstrato/trabalho concreto, trabalho produtivo/trabalho improdutivo, dentre outras. A teoria da exploração é exposta por Karl Marx no decorrer da critica da economia política, alcançando na obra "0 Capital" (1867) seu ápice de desenvolvimento científico.

A teoria do estranhamento é o complexo categorial que explica a desefetivação do ser genérico do homem que trabalha a partir das relações sociais/ práxis histórica, constitutivas do trabalho estranhado e da vida social estranhada subjacente à produção do capital (relações sociais entre sujeito/objeto mediadas pelas relações sociais sujeito/sujeito).

Os elementos primordiais da teoria do estranhamento estão expostos nas obras de juventude de Marx, com destaque para os "Manuscritos de Paris" (1844). Mesmo em "0 Capital", de 1867, a discussão sobre o fetiche da mercadoria e seu segredo remete à teoria do estranhamento, na medida em que Marx explica, a partir da forma-mercadoria, uma determinada forma de consciência social estranhada (na verdade, a teoria do fetichismo é um desdobramento teórico-categorial interno da própria teoria do estranhamento nas condições do capitalismo histórico).

Portanto, enquanto a teoria da exploração trata do "em-si" e da dimensão estrutural e, portanto, das leis tendenciais históricas do modo de produção capitalista, a teoria do estranbamento trata do "para-si" e do conteúdo material da práxis histórica (as relações sociais). É importante salientar que a divisão entre teoria da exploração e teoria do estranbamento é meramente heurística, tendo em vista que a exploração sempre pressupõe estranhamento (ou trabalho estranhado) e o trabalho estranhado, sob o modo de produção capitalista, pressupõe exploração.

\section{A CONDiÇÃo DE PROLETARIEDAdE}

A condição de proletariedade é o elemento fundante (e fundamental) do trabalho estranhado: só há trabalho estranbado ou trabalho assalariado porque há proletários ou homens e mulheres imersas numa condição histórico- 
existencial de proletariedade, obrigados, pela necessidade de sobrevivência, a se submeterem às condições da exploração capitalista. Mas pode-se dizer também que só há proletários porque há trabalho estranhado como modo de produção de mercadorias baseado na exploração da força de trabalho. A condição de proletariedade é produzida (e reproduzida) pelo modo de trabalho (e vida) capitalista. Nesse caso, o trabalho estranhado - ou trabalho assalariado - aparece como o modo de ser da expropriação como alienação sistêmica ou alienação reiterativa do sistema sociometabólico do capital.

A condição de proletariedade é produzida pelo ato histórico de alienação primordial (a assim dita "acumulação primitiva"), reposta historicamente pelo desenvolvimento capitalista, isto é, reproduzida pela alienação sistêmica, que aparece sob a forma do trabalho estranhado. Por isso, é interessante dissecarmos as dimensões do trabalho estranhado e vida social estranhada para apreendermos, deste modo, o metabolismo social da condição histórico-existencial de proletariedade.

No Terceiro Manuscrito intitulado "Trabalho Estranhado" (Entfremdung Arbeit) dos "Manuscritos de Paris" ou "Manuscritos econômico-filosóficos" (de 1844), Karl Marx desvela os elementos que constituem, em si e para si, o que chamamos de condição de proletariedade. Na verdade, Marx expôs a natureza do trabalho estranhado e suas derivações sócio-reprodutivas (o estranhamento social). Nesse texto, ele não trata somente da produção social, mas também de elementos da reprodução social, expondo assim, o metabolismo social da própria condição de proletariedade.

Primeiro, Marx se posiciona na perspectiva na totalidade social. Ele não desvincula trabalho e vida; para homens e mulheres imersos na condição de proletariedade, trabalho é vida e vida é trabalho. Inclusive, o trabalho estranhado, no tocante as suas derivações sistêmicas, envolve também aqueles que não estão vinculados direta ou indiretamente à produção do capital propriamente dito (na mesma medida em que, na sociedade do fetichismo, a forma-mercadoria impregna os produtos-objetos que não são mercadorias propriamente ditas).

Karl Marx trata de um sistema social baseado no trabalho estranhado cuja vida social é estranhada em suas múltiplas manifestações vitais. 0 que significa que a condição de proletariedade é uma condição universal - no sentido de dizer respeito a uma condição ontológica do homem proletário subsumido ao trabalho estranhado, fundamento orgânico do processo de modernização do capital -, que tende a se universalizar, pois o modo de produção do capital tem como uma 
de suas características ontológicas, a expansidade e universalidade em si e para si. Enfim, o processso de efetivação da condição de proletariedade no sentido de sua universalização acompanha o movimento voraz do capital como "sujeito automático" que constitui a modernidade-mundo.

Ao tratar do trabalho estranhado, em 1844, Karl Marx colocou os primeiros rudimentos da sua critica da sociedade burguesa. Naquela época, Marx ainda não tinha desenvolvido sua teoria critica do capital, faltando-lhe maior clareza sobre os nexos categoriais constitutivos do modo de produção capitalista e da dinâmica da acumulação de capital. Entretanto, consideramos que o jovem Marx colocou diante de si, o eixo estruturante de sua intervenção critico-intelectual que ele iria aprimorar no decorrer dos anos por meio de sua crítica da economia política.

0 conceito de trabalho estranhado, base estruturante da vida estranhada, delineia-se no decorrer da apresentação que o jovem Marx faz desta totalidade concreta do mundo burguês. São perceptíveis os nexos essenciais entre produção e reprodução social, trabalho e vida cotidiana, objetividade e subjetividade do homem que trabalha. Eles compõem uma totalidade na qual está imerso o individuo social de classe. Estamos diante de uma arquitetura categorial complexa daquilo que denominamos de "condição de proletariedade", construto teórico-analitico que busca apreender as implicações objetivas e subjetivas da perda (ou da negação) do homem como ser genérico no sistema do capital.

Para Marx, o trabalho estranhado possui múltiplas dimensões que se desvelam na medida em que ele discorre dialeticamente, no Terceiro Manuscrito, sobre as interconexões causais obnubiladas pela perspectiva da economia política (ele salienta os pólos aparentemente antípodas - pobreza e riqueza e trabalho e vida social).

0 trabalho estranhado ou trabalho assalariado é uma forma histórica do trabalho humano-social. A base fundante (e fundamental) de toda forma histórica de trabalho é o trabalho como categoria ontológica do ser social. 0 trabalho como categoria ontológica do ser social é o pressuposto negado (mas efetivo) do trabalho estranhado e do trabalho capitalista como forma histórica particular-concreta de trabalho. Nesse caso, o "trabalho estranhado" existiu em formas sociais pré-capitalistas (como o trabalho escravo ou o trabalho servil). Mas o trabalho capitalista (ou trabalbo assalariado) é uma forma bistórica mais desenvolvida, capaz, portanto, de explicar as formas pretéritas de trabalho $e$ estranbamento social (LUKÁCS, 1981) 
A condição de proletariedade se desenvolve com o trabalho estranhado capitalista. Ela emerge com a modernidade do capital, tornando-se condição universal das individualidades de classe despossuídas da propriedade dos meios de produção da vida social. A condição de proletariedade se caracteriza, portanto, pelos elementos compositivos da relação-capital no plano das individualidades alienadas ou "trabalhadores livres". Homens e mulheres imersos na condição de proletariedade são individualidades sociais que não possuem a propriedade e/ou a posse (e, portanto, o controle) das condições de produção da vida social. É a partir desta condição sócio-estrutural alienada que podemos derivar as múltiplas atribuições existenciais da proletariedade moderna ou condição de proletariedade.

A idéia de "condição", nesse caso, é dada quase como um "destino". 0 que significa que, cada um de nós, nasce numa determinada condição bistóricoexistencial transmitida de geração em geração. A condição de proletariedade é a condição histórico-existencial da modernização do capital que se caracteriza pela despossessão irremediável do homem que trabalha das condições objetivas e subjetivas da produção da vida social. Esta despossessão (ou alienaçãa) irremediável é o que tem caracterizado a história do Ocidente desde o século XVI, com destaque para a despossessão de camponeses, pequenos artesãos e comerciantes atingidos pelo processo de proletarização.

0 conceito de proletarização significa o processo de despossessão objetiva (e subjetiva) dos meios de produção da vida social. A perda da propriedade pessoal e a imersão na condição de proletariedade, que os constitui como individualidades de classe, é o processo de proletarização. A proletarização joga homens e mulheres despossuídos no mundo social da "classe" do proletariado (ainda não caracterizados enquanto classe social em si ou para si). Nesse caso, ocorre a passagem da individualidade pessoal, marcada pelo domínio imediato de meios (e instrumentos) de produção da vida social e comunitária, para a individualidade de classe, marcada pela despossessão destes meios (e instrumentos) de produção da vida e subalternização diante das condições objetivas (e subjetivas) da produção do capital (o que não significa que a dimensão pessoal da individualidade bumana seja abolida, mas é apenas sobredeterminada, constituindo-se o que denominamos individualidade pessoal de classe) (ALVES, 2009).

Deste modo, o homem proletário é o homem imerso na relação-capital que implica, por um lado despossessão (a alienação do objeto constituindo 
diante de si, o poder da propriedade privada); e por outro lado, subalternidade 3 . A passagem categórica da individualidade pessoal para a individualidade de classe significa a submersão na vida contingente e a imersão no acaso. Na verdade, o processo de proletarização que marca a ocidentalização do mundo constituiu um novo tipo bumano, o homem submetido às coisas ou ao poder das coisas, como diria Marx.

Enfim, o bomem alienado ou homem desefetivado como sujeito, é o homem moderno, homem burguês, dividido em si e clivado de contradições diante do mundo social reificado. Trata-se de uma condição histórico-existencial e não uma condição ontológica do homem como ser jogado no mundo e destinado à morte, como supõe algumas correntes filosóficas que elevam a condição de proletariedade a uma condição ontológica do homem. Deste modo, o existencialismo ateu, com sua metafísica da angústia, expressa, na verdade, os traços históricos do pleno sentimento da alienação capitalista.

Portanto, é do processo social de proletarização, processo originário e sistêmico do metabolismo social do capital, que emerge a condição de existência (des)humana da civilização do capital, a "condição de proletariedade", caracterizada por uma série de atributos histórico-existenciais que se disseminam pela sociedade burguesa: subalternidade, acaso e contingencia, insegurança e descontrole existencial, incomunicabilidade, corrosão do caráter, deriva pessoal e sofrimento. Podemos destacar ainda outros traços histórico-existenciais como risco e periculosidade, invisibilidade social, experimentação e manipulação, prosaísmo e desencantamento ${ }^{4}$.

Tais atributos existenciais da "condição de proletariedade" permeiam as múltiplas relações sociais, direta ou indiretamente ligadas à produção/reprodução social do sistema do capital. Elas se tornam atributos existenciais da vida burguesa atingindo, por derivação e difusão, a cotidianidade de proletários e nãoproletários propriamente ditos.

\footnotetext{
${ }^{3}$ A alienação da atividade ou do processo de trabalho, sendo deste modo, no plano da reprodução social o homem proletário, um ser subalterno às objetivações sociais - classe social, ideologia, Estado político, salário. Assim, o proletário como individuo de classe está imerso na subalternidade dada pela divisão hierárquica do trabalho, e na contingência e acaso, dada pelas relações de mercado.

${ }^{4}$ Por exemplo: é o prosaísmo da vida burguesa que impele as individualidades pessoais de classe a se projetarem em "fantasias heróicas" que tende a elevá-las, sob determinadas circunstâncias, acima da pseudoconcreticidade da vida cotidiana.
} 
0 ser "proletariado", no sentido fraco da palavra, diz respeito a uma condição objetiva de existência (ou "condição de proletariedade") cujos atributos existenciais tendem a se tornarem, sob a sociedade burguesa, atributos universais das individualidades pessoais de classe. 0 ser proletariado pode dizer respeito também a uma classe social no sentido pleno de sujeito histórico-coletivo, com maior ou menor efetivação (o que exige outras mediações concretas como instituições sociais, políticas ou culturais capazes de produzir um tipo específico de consciência social: a consciência de classe).

\section{O CONCEITO DE “CLASSE SOCIAL”}

A condição de proletariedade, condição histórico-particular que surge com a modernidade do capital (e que se amplia e expande nos últimos séculos) põe a possibilidade objetiva da "classe social" como categoria sociológica, classe social como sujeito histórico-coletivo.

0 conceito de classe social, com o "proletariado" constituindo a classe social por excelência, é um dos conceitos sociológicos da maior relevância epistemológica. $\mathrm{Na}$ verdade, é um conceito científico indispensável para a episteme da emancipação social (o que explica o desprezo que as ideologias liberais e pós-modernas, ideologias conservadoras da ordem do capital, têm com 0 conceito de classe social). A rigor, a classe social do proletariado é a classe social por excelência porque só ela, e não a burguesia, tem a possibilidade concreta e tão-somente a possibilidade - de promover a "negação da negação", isto é, a negação da condição de proletariedade por meio da constituição processual da consciência de classe e luta de classe (classe social no sentido de sujeito histórico capaz de transformação histórica efetiva). Assim, o "proletariado" é a classe social por excelência porque é a única "classe" capaz de, sob determinadas condições, ir além da condição de proletariedade, negando, deste modo, a relação-capital.

Na verdade, capital e trabalho assalariado são determinações reflexivas da relação-capital e não meros "pólos" da relação social fundamental e fundante da modernidade burguesa. É importante lembrar que o léxico dialético não utiliza o termo "pólos", mas, sim, "determinações reflexivas", contraditórias e antagônicas, cujo movimento efetivo do real pode conduzir (ou não) à superação (Aufhebung) da relação social antagônica. Nesse caso, a rigor, a abolição da relação-capital pressupõe não apenas a abolição do capital, mas também a abolição/emancipação da sua determinação reflexiva: o trabalho assalariado. 
A condição de proletariedade põe apenas a possibilidade objetiva da "classe social", mas quem a constitui efetivamente, no sentido da classe em si e para si, é a luta de classe, isto é, o movimento social da "classe" mediado pelas instituições políticas e culturais capazes de propiciar, por meio de processos de subjetivação radical e organização social, política e cultural, a formação da consciência de classe. Existe um largo espectro de formas de ser da consciência de classe em sua processualidade sócio-histórica, um continuum complexo de formas de consciência social que percorre as dimensões da pré-contingencia ou ainda as dimensões da contingência e necessidade, isto é, do "em-si" e do "para-si" da classe.

Como salientamos acima, buscamos elaborar, a partir de Marx (e não segundo Marx), uma teoria do proletariado como sujeito histórico coletivo, tomando como ponto de partida, a teoria do estranhamento ${ }^{5}$ e não a teoria da exploração, como tem sido comumente tratada pela tradição marxista (0 que pressupõe salientar a idéia de formação da classe como sujeito históricocoletivo). Obviamente, não desprezamos a teoria da exploração tendo em vista que ela constitui a base material-objetiva da própria condição de proletariedade. Entretanto, na medida em que, a teoria do estranhamento diz respeito ao processo de (de)formação do sujeito humano como ser genérico, ela se torna o elemento categorial capaz de explicar a constituição da classe social do proletariado como sujeito histórico capaz de "negação da negação".

Além disso, ao dizermos que elaboramos uma teoria do proletariado "a partir de" Marx e não "segundo Marx" (como supõe uma leitura imanente de "O Capital", por exemplo) significa que algumas afirmações podem não estar de acordo literalmente com Marx, tendo em vista que o objeto categorial visado por Marx no século XIX não é o objeto categorial que visamos no século XXI. Na medida em que o capitalismo (e o proletariado) visado por Marx é (e não é) o capitalismo (e o proletariado) visado por nós, uma teoria do proletariado segundo Marx não seria uma teoria científica. Na verdade, segundo o método dialético, todo conceito (como o de "proletariado") é uma categoria, ou seja, é uma forma de ser e modo de existência historicamente determinada.

\footnotetext{
${ }^{5}$ A teoria do estranhamento é uma teoria da negação/afirmação do sujeito humano-social. É por isso, uma teoria da práxis que se distingue, em seu estatuto epistemológico, da teoria da exploração, como teoria das estruturas (ou mecanismos) do movimento do capital (uma teoria da classe do proletariado a partir da teoria da exploração seria meramente a teoria de uma "classe em inércia" - o que é uma contradição em termos. A rigor, "classe em inércia" é a própria "negação" da categoria de classe social como fato onto-epistemológico inovador da modernidade do capital) (para uma teoria das classes - como "classe em inércia" - vide FAUST0, 1986).
} 
Tornou-se corriqueiro na tradição marxista, ao se discutir o conceito de proletariado, tratar-se, de imediato, da questão do "trabalho produtivo" e "trabalho improdutivo", como se o problema da classe do proletariado pudesse ser resolvido a partir desta distinção sócio-estrutural. Deste modo, tende-se a reduzir proletariado aos "trabalhadores produtivos" (na verdade, esta é a visão marxiana historicamente determinada). Mas o pior é que se presume também, sem questionamentos, que o proletariado como sujeito histórico-coletivo, ou seja, como "classe social" no sentido legítimo da expressão categorial, é um dado sociológico-estrutural ligada a uma posição objetiva na divisão social do trabalho. Por isso, imagina-se que é suficiente identificar, segundo a ótica da teoria da exploração, os atributos estruturais da classe do proletariado.

Consideramos que esta mudança de enfoque analítico (tratar da classe do proletariado a partir da teoria do estranhamento) contribui para expor em nossos dias aspectos novos do significado de "proletariado" segundo as condições do capitalismo desenvolvido no século XX. Por exemplo, segundo a ótica dialéticomatarialista (e histórica) que apresentamos, a título de hipótese, proletariado aparece como "classe" (com aspas), no sentido de condição de proletariedade; e como classe, no sentido de "classe em si/classe para si" (enfim, proletariado como classe pressupõe algum grau de consciência de classe).

A categoria de proletariado como classe, ou seja, como sujeito históricocoletivo, é radicalmente uma construção histórica da mais alta relevância e não um mero dado sociológico-estrutural. Isto é, o proletariado (como classe) não nasce feito, mas se faz no devir histórico, fazendo-se e desfazendo-se; tornando-se visível e invisível, dependendo das condições históricas específicas.

Entendemos que o conceito de classe social tem uma importância fundamental no materialismo histórico, sendo o ponto de partida da própria critica da economia política. Entretanto, nem Marx nem Engels formularam de maneira sistemática o conceito de classe social.

A materialidade intensamente social e agudamente contraditória do modo de produção capitalista constitui ontologicamente a categoria em si de classe social. A descoberta do "proletariado" na década de 1840 significou para Marx e Engels a descoberta do "movimento real que supera o estado de coisas atual" (como afirmam na "Ideologia Alemã"). Eles observaram que a "própria classe é um produto da burguesia". Deste modo, "classe" é uma categoria distintiva da sociedade burguesa. Podemos dizer que nas sociedades pré-capitalistas não 
havia propriamente "classes sociais", mas grupos de status, ordens, e múltiplas gradações de categoriais sociais.

Embora Marx afirme a existência de uma divisão fundamental de classes em todas as formas de sociedade que sucederam as antigas comunidades tribais, divisão fundamental de classe baseada na relação direta entre proprietários das condições de produção e os produtores diretos, que segundo ele (n'O Capital), "revela o segredo mais íntimo, o fundamento oculto de todo edifício social" (MARX, 1983, p. 251), consideramos que o significado pleno de "classe" só aparece na sociedade burguesa, e que tem no proletariado não apenas uma das classes fundamentais, mas a classe social propriamente dita que expressa como potentia o sentido ontológico da "classe" como sujeito histórico.

Deste modo, podemos distinguir duas acepções de "classe":

Primeiro, existe uma acepção sociológica de "classe" que distingue na sociedade capitalista duas classes fundamentais em função da divisão social do trabalho: a classe dos trabalhadores assalariados e a classe da burguesia. Classe, nesse sentido, possui um significado funcional-estrutural (funcional para o capital), como aparece nesta passagem do livro "Miséria da Filosofia" (de KARL MARX, de 1847). Diz ele:

As condições econômicas transformaram, em primeiro lugar, a massa do povo em trabalhadores. A dominação do capital sobre os trabalhadores criou a situação comum e os interesses comuns desta classe. Assim, essa massa já é uma classe em relação ao capital, mas não ainda uma classe para si mesma. Na luta, da qual indicamos apenas algumas fases, essa massa se une e forma uma classe para si. Os interesses que ela defende tornam-se interesses de classe. (MARX, 1985, p. 124).

Em síntese, os capitalistas ou os proprietários das condições de produção de um lado e, por outro lado, os trabalhadores assalariados ou os produtores diretos (ou indiretos, no caso de sociedades de classe mais complexas), constituem as classes fundamentais da sociedade burguesa. Nesse sentido, "classe" possui um significado mais sociológico propriamente.

Ainda nesta acepção descritiva de classe social, temos a categoria intermediaria de "classe média" que no decorrer do capitalismo tende não apenas a crescer numericamente, mas a adquirir feições próprias no decorrer de cada estágio de desenvolvimento histórico do sistema do capital. A utilização do termo "classe média" possui outro estatuto teórico-analitico: é mais uma categoria da 
estratificação social do que propriamente da estrutura de classes, embora, como iremos verificar adiante, a estratificação social exerce sua efetividade categorial no processo de constituição da classe "para si".

Segundo, temos a acepção dialético-materialista, na que classe não é apenas um mero conjunto sócio-estatistico inserido numa determinada posição objetiva da divisão social do trabalho, ou seja, "classe para o capital", mas sim uma coletividade organizada de produtores ou trabalhadores alienados das condições de produção que possui uma determinada forma de consciência social: a consciência de classe ("classe para si", isto é, classe com interesses de classe). Enfim, a forma de ser da classe social, na ótica dialético-metarialista, pressupõe não apenas uma posição objetiva na divisão social do trabalho, mas uma determinada forma de consciência social, a consciência de classe capaz de transformar em si e para si aquela coletividade particular-concreta de trabalhadores proletários em sujeito histórico real (a classe do proletariado), cujo movimento social e político tende a "negar" o estado de coisas atual. Esta é a acepção efetiva (e original) da categoria de "classe social" na ótica marxiana.

Dizer "proletário" ou mesmo "proletariado" não significa efetivamente dizer "classe do proletariado". 0 homem proletário ou o proletariado em si está apenas subsumido à condição de proletariedade, matéria social como categoria histórica. Nesse caso, o que iremos denominar de "condição de proletariedade" possui apenas a potentia e não o acto da categoria de classe social (o que não é pouca coisa). Uma de nossas teses é que, na perspectiva dialética-materialista, a rigor, só há efetivamente classe se houver consciência de classe.

A categoria de "classe social" é uma das categorias fundamentais da sociologia critica. Mais uma vez, salientamos que ela não se reduz a mera estatística social de posições funcional-estruturais. A efetivação categorial da classe pressupõe não apenas uma materialidade objetiva ou posição na divisão social de trabalho e antagonismo estrutural de interesses de classe, mas sim, materialidade subjetiva ou experiência de classe e consciência de classe.

Deste modo, apenas a classe em-si e para-si constitui efetivamente a classe social como categoria histórica. Ao dizermos classe em-si e para-si dizemos a constituição de um sujeito histórico com determinado grau de consciência de classe contingente ou necessária. A constituição do sujeito de classe é processual, percorrendo uma gradação progressiva (ou regressiva) que vai da consciência de classe contingente, classe em-si, momento estrutural da percepção e do 
entendimento das individualidades de classe, à consciência de classe necessária, classe para-si, momento histórico-político da experiência de classe que tende a se generalizar (MÉSZÁROS, 2008).

Pode-se inclusive conceber, neste processo histórico, outro momento da consciência social, a consciência de classe para-além-de-si, que diz respeito à dimensão da genericidade humana para além da divisão da sociedade em classe. $\mathrm{Na}$ verdade, a consciência de classe propriamente dita ou consciência de classe necessária, traduz-se na superação do momento econômico-corporativo pelo momento ético-político (embora, é claro, o momento dapercepção de classe nos seus mais diversos graus de percepção, ou a consciência de classe contingente, seja efetivamente consciência de classe in fieri).

0 movimento da consciência social para a consciência de classe (que no plano epistemológico implica a passagem da consciência ingênua para a consciência critica) é um momento de catarse das individualidades pessoais de classe em sipara si que ocorre a partir das suas experiências vividas e experiências percebidas de classe (como condição objetiva dada), experiências cotidianas mediadas por instituições (ou movimentos) culturais ou políticas capazes de ir além dapseudo-concreticidade (na acepção de Karel Kosik) (KOSIK, 1978).

A consciência de classe capaz de constituir a nova forma de ser da coletividade de produtores sociais (a classe em-si e para-si), que é a classe social propriamente dita, sujeito histórico capaz de lutar pelos interesses de classe na cena sindical, política e social, emerge de uma condição material (e situação objetiva) historicamente dada e socialmente constituída pelo modo de produção capitalista. No caso da classe do proletariado, a condição material (e situação objetiva) historicamente dada que constitui ontologicamente a classe social no sentido da forma de ser da classe - é o que temos denominado de condição de proletariedade. Esta condição objetiva dada é a matriz sócio-estrutural da formação da classe social como sujeito histórico da modernidade do capital.

\section{“Classe” e Classe do proletariado}

Utilizamos "classe" (com aspas), para salientar o caráter meramente potencial do conceito ou categoria como forma de ser. A "classe" do proletariado, constituída por homens e mulheres que estão imersos na condição de proletariedade, não é, a rigor, a classe do proletariado que pressupõe como elemento constitutivo, 
fundante e fundamental, a consciência de classe em-si e para-si. Na verdade, a categoria de "classe social" é uma categoria-espectral no sentido de categoria que se desvela no movimento efetivo do real histórico, não sendo, portanto, uma categoria dada de imediato (por exemplo, Marx e Engels dizem na abertura clássica do "Manifesto Comunista" de 1848: "Um espectro ronda a Europa - 0 espectro do comunismo". Nesse caso, "espectro do comunismo" significa 0 movimento potencialmnete efetivo em processo de constituição capaz de negar o statu quo) Ora, a classe social como categoria-espectral não apenas se constitui historicamente (e cotidianamente), como pode se desconstituir, desaparecendo efetivamente enquanto classe, tornando-se meramente "classe" do proletariado.

Portanto, a rigor, podemos dizer que existem individualidades pessoais de "classe" (com aspas), homens e mulheres jogados no mundo social do capital, despossuídos, subalternos e imersos na contingência de vida e no acaso do mercado; e individualidade pessoais de classe, homens e mulheres em processo de subjetivação de classe, sujeitos em constituição por meio de processos históricosociais, que buscam dar respostas organizativas, associativas e políticas aos constrangimentos da ordem sócio-metabólica do capital a partir de seus interesses objetivos de classe.

Segundo, o elemento de despossessão, que constitui (e marca) a condição de proletariedade, precisa ser mais bem qualificado. A princípio, ao dizermos "despossessão", queremos ressaltar a perda/alienação dos meios objetivos e subjetivos de produção da vida social. É o processo de proletarização que constitui a condição de proletariedade e, por conseguinte, a "classe" do proletariado. Entretanto, é importante salientar situações de "classe" que estão numa situação intermediária. 0 que significa que a despossessão é mediada por situações de posse às mais diversas. Isto é importante para o entendimento das situações de "classe intermediária" (ou de "classe média"), em que a proletarização não está posta efetivamente, mas tão-somente pressuposta em diversos graus. Uma teoria das posses se torna essencial para o entendimento dos obstáculos efetivos à consciência de classe e à constituição da classe do proletariado.

Por exemplo, há situações de grupos sociais ou estratos de trabalhadores que embora não sejam proprietários dos meios de produção, têm a posse destes meios ou instrumentos de produção da vida social. Este dado objetivo provoca um "deslocamento" no processo de subjetivação de classe, colocando obstáculos efetivos (ou virtuais) à constituição da consciência de classe proletária e, 
portanto, da sua identificação com a classe do proletariado. Isto vale não apenas para a chamada "pequeno-burguesia" clássica (por exemplo, pequenos camponeses, comerciantes e artesãos, que na medida em que o sistema mundial do capital se desenvolve não têm o controle da produção da vida, embora tenham a posse dos meios de produção), mas uma "nova pequeno-burguesia", que surge com o desenvolvimento do capitalismo industrial. Embora eles não tenham a propriedade (ou o controle) efetiva da produção da vida social, têm a posse simbólica dos meios (ou instrumentos) de produção. Isto é, embora sejam, em tese, trabalhadores assalariados, têm a posse de prerrogativas de mando/gerência ou chefia e/ou ainda habilidades técnico-instrumentais, posses que garantem determinados status ou prestigio na ordem social do capital (com contrapartida na capacidade aquisitiva ou renda monetária).

No caso dos estratos técnico-especializados ou trabalhadores de "classe média", por terem maior qualificação/competência tendem a incorporar como suposto "capital humano" tais atributos profissionais. Nesse caso, a posse como obstáculo à constituição da consciência de classe e, portanto, obstáculo à constituição da própria classe do proletariado, pode assumir um caráter simbólicoinstrumental, atingindo parcelas amplas do proletariado das indústrias e dos serviços.

A dimensão simbólica da posse é dada não apenas pelas habilidades técnico/cognitivas, mas, no limite, a posse de mercadorias de luxo que conferem status e prestigio a quem o possui. Na medida em que o mundo social do capital é uma "imensa coleção de mercadorias" e que o desenvolvimento da produção de mais-valia relativa permite que uma parcela ampla do proletariado, em virtude da pressão organizada, sindical e política, conquiste maior participação na riqueza social produzida como mercadorias e serviços, amplia-se o contingente do proletariado implicado na ordem simbólica da ideologia pequeno-burguesa, em que a posse das coisas tende a ocultar a condição de proletariedade, e por conseguinte, tende a obstaculizar, sob determinadas condições, a constituição da classe do proletariado.

A disseminação do fetichismo da mercadoria no bojo do capitalismo industrial, marcado pela produção ampliada de riqueza social, é uma intensa "força gravitacional" que desloca o desenvolvimento da consciência de classe do proletariado, colocando amplos contingentes do mundo do trabalho despossuído no horizonte simbólico da ordem burguesa. 
Na verdade, o desenvolvimento do capitalismo industrial cria uma aguda contradição entre condição de proletariedade, condição universal de homens despossuídos da propriedade e do controle dos meios de produção da vida social, e situações de consciência social impregnadas da ideologia pequeno-burguesa sob o estigma da posse como obstáculo decisivo à constituição efetiva da classe do proletariado (posse de poder e posse de dinheiro).

Ora, a luta suprema do capital é impedir o surgimento da classe do proletariado, a classe capaz de negar o estado de coisas existentes, caracterizado pela alienação do controle social (o problema do fetichismo). Efetivar a negação da condição de proletariedade significa assumir as rédeas do controle social impregnado pela lógica da valorização do valor e do mercado. Mesmo os trabalhadores "por conta própria" e os trabalbadores "autônomos", que aparentemente são proprietários dos meios de produção, não sendo considerados "proletários" no sentido estrito da palavra, são homens e mulheres subalternos à ordem sócio-metabólica do capital, tendo em vista que não têm o controle da produção social nas condições de uma sociedade cada vez mais socializada. Em alguma medida, estão imersos na condição de proletariedade, embora a situação de propriedade lhe seja atribuída ${ }^{6}$.

Por outro lado, diante do "corpo social" de despossuídos do controle social aparece o capital em geral, constituído pela oligopolização capitalista e seus agentes executivos (as personas do capital). Assim, podem-se distinguir gradações ontológicas (ou modos de efetivação) do proletariado, ao dizermos "classe" do proletariado dizemos individualidades pessoais de classe imersas na "condição de proletariedade". O proletariado como classe social propriamente dita pressupõe o movimento de classe em si/classe para si (ou para além-de-si) e, por conseguinte, o movimento da consciência de classe. De outra maneira, a consciência de classe é uma forma de consciência crítica, que assume uma forma contingente e forma necessária.

Em síntese, podemos dizer que:

A "classe" do proletariado e a "classe" da burguesia são os pólos de classe fundamentais do modo de produção capitalista. 0 primeiro pólo social são os trabalhadores assalariados, expropriados/alienados dos meios de produção da

\footnotetext{
${ }^{6}$ A rigor, a propriedade se interverte em "posse", tendo em vista que, mesmo como "proprietários", possuem uma relação de subalternidade com o grande capital oligopólico, não tendo, portanto, o controle do mercado que os submete.
} 
vida. 0 segundo pólo social são os capitalistas, grandes proprietários dos meios de produção que acumulam riqueza através da mobilização (e exploração) dos trabalhadores assalariados.

Mas encontramos na sociedade burguesa um conjunto de "situações intermediárias/excêntricas": Primeiro, a "classe" de pequenos e médios proprietários que obtém recursos por meio da exploração (de trabalhadores assalariados) e que compõem uma pequeno-burguesia proprietária. É uma "classe média" proprietária de estirpe tradicional.

Segundo, é importante discriminar, a categoria de "nova classe média", trabalhadores assalariados de "colarinho branco"/personas do capital, construção categorial sociologicamente exótica tendo em vista que implica o cruzamento de referentes da estrutura de classes/divisão social do trabalho e elementos da estratificação social (status, prestigio e renda) com derivações específicas no plano da consciência social (quase-impossibilidade de consciência de classe).

E por fim, a categoria de lumpen-proletariado, estrato/sedimento da "classe" do proletariado, "desligado" das possibilidades de mobilidade social e consciência de classe por conta da imersão extrema na "condição de proletariedade".

Podemos dizer, a título de considerações finais que, na medida em que o capital amplia e intensifica a "condição de proletariedade", as formas de fetichismos sociais impedem (e colocam obstáculos significativos) à consciência de classe. A luta política de classe é a luta para superar os fetiches como obstáculos sociais. 0 estudo das múltiplas formas de fetichismo social se torna importante na elaboração de estratégias de formação de classe, no sentido de sujeito histórico coletivo, único agente social moderno capaz de transformação social na era da modernidade do capital, no interior da condição proletária universal (o que exige levar em consideração o complexo de situações concretas de proletariedade). Nesse texto buscamos tratar de uma necessidade ontológica da formação da classe conduzida por uma instância/processo político-teleológico "exterior" à dinâmica da pseudo-concreticidade no qual estão imersos os proletários como "classe".

\section{REFERÊNCIAS}

ALTHUSSER, Louis; BALIBAR, Étienne. Lire le Capital. Paris: Maspero, 1973.

ALVES, Giovanni. A condição de proletariedade. Bauru: Práxis, 2009.

BOURDIEU, Pierre. La distinction: critique sociale du jugement. Paris: Minuit, 1979. 
. Le sens pratique. Paris: Minuit, 1980.

BRENNER, Johanna. Work relations and the formation of class consciousness. In: WRIGHT, Erik Olin (Org.). The debate on classes. London: Verso, 1998. p. 184-190. COHEN, Gerald Allan. Karl Marx's theory of history: a defense. New Jersey: Princeton University Press, 1978.

ESTANQUE, Elisio. Classes e desigualdades sociais em Portugal: um estudo comparativo. Porto: Edições Afrontamento, 1997.

FAUSTO, Ruy. Marx: lógica e política. São Paulo: Brasiliense, 1986.

GIDDENS, Anthony; HELD, David. Classes, power, and conflict: classical and contemporary debates. London: MacMillan, 1982.

GRAMSCI, Antonio. Obras escolbidas: I e II. Lisboa: Estampa, 1974.

HOBSBAWM, Eric. Class consciousness in history. In: ALCOFF, Linda Martín; MENDIETA, Eduardo (Ed.). Identities: race, class,gender and nationality. Oxford: Blackwell, 2003. p. 126-135.

KOSIK, Karel. Dialética do concreto. Rio de Janeiro: Paz e Terra, 1978.

LUKÁCS, Georg. Ontologia dell'essere sociale. Roma: Riuniti, 1981.

MARX, Karl. Manuscritos econômico-filosóficos. São Paulo: Boitempo, 2004. . Miséria da filosofia. São Paulo: Global, 1985. . O capital: critica da economia política, livro 3, t.2, São Paulo: Abril Cultural, 1983.

MÉSZÁROS, István. Filosofia, ideologia e ciência social: ensaios de negação e afirmação. São Paulo: Boitempo, 2008.

. Para além do capital: rumo a uma teoria da transição. Campinas: Ed. UNICAMP, 2002.

POULANTZAS, Nicos. Classes in contemporary capitalism. London: NLB, 1975.

SILVA, Manoel Carlos. Classes sociais: condicção objetiva, identidade e acção coletiva, Ribeirão: Húmus, 2009

THOMPSON, E. P. The making of the english working class. Harmondsworth: Middlesex, 1982.

WRIGHT, Eric Olin. Classes. London: Verso, 1985. Reflections on classes. In: (0rg.). The debate on classes. London: Verso, 1998. p. 49-77. 